\title{
CARnivorous Plants of THE WeStern AUSTRALIAN GRANITE OUTCROPS
}

BoAz NG・Sydney • New South Wales • Australia •ng.boaz@gmail.com

At the end of winter in 2019 I embarked on an expedition to Western Australia to find carnivorous plants in the wild. This region is a center of diversity for carnivorous plants, with more than 100 endemic species. My journey took me on a long circuit around the countryside, starting with a drive through the forests of the South West towards the Great Southern coastline, then heading north east to the interior Wheatbelt region, before eventually looping back to Perth. Throughout my 17 days and roughly 3000 kilometers on the road, the geographical features that struck me most were the granite outcrops. These ancient landforms dominate the weathered landscape and give rise to unique habitats on which countless flora and fauna have evolved. It was in these granite ecosystems that I observed the most impressive displays of Drosera and Utricularia.

My journey began in a hurry as my plane landed late in Perth, and I was impatient to set off and begin the exploration of a lifetime! Hastily, I picked up the rental car, bought supplies for the next few days, and it wasn't long until I was on the highway driving at speed out of the city. In preparation for the trip, I had armed myself with a list of coordinates sourced from publicly available datasets, personal communications, and likely habitats that I had identified by scrutinizing Google Maps. This expedition was to be efficient, visiting a sure set of roadside locations as to leave enough time for some real exploration of the unknown. After a hurried half day of travel, I arrived in Bunbury and went to sleep early in preparation for a long day ahead.

The following morning, I woke up before sunrise to explore a nature park in the area, before setting off on the $250 \mathrm{~km}$ drive to the southern village of Walpole. After a few hours driving through agricultural pastures, I suddenly found myself surrounded by gigantic karri trees as I entered the forests of the South West. Here, high winter rainfalls and comparatively mild temperatures support the growth of dense forests, which are protected within the vast national parks the region is renowned for. It wasn't long before I arrived at my first site.

As I turned a corner, the canopy suddenly opened, and I was confronted with a gigantic granite outcrop smack on the road side. The grand monolith punctuated the dense forest surroundings, occupying the area of a sports field and rising some three stories high. Stained green with lichen and covered with a thick layer of moss, the rock seemed like a living entity, beckoning me to practically run out of the car to begin searching for carnivorous plants. Immediately at its base, I saw thousands of pink blooms dotting the swampy moss and realized that they were the flowers of Utricularia multifida (Fig. 1). I was worried that I would miss out on seeing this species of terrestrial bladderwort, which is known for its impressive en mass floral displays, but luck was on my side. As I traversed the outcrop, I spotted curious red tufts of sundews periodically sprouting up from the open moss. Upon closer inspection I found that these were Drosera macrantha, a scrambling species with long stems which, in the absence of a supporting perch, were windswept into tight balls. Climbing to the top of the outcrop, I began to appreciate the range of microniches that developed in different areas of the rock. The top of the monolith was plateaued out, and an accumulation of peat supported the growth of bushes. Intertwined within this scrub, I discovered D. erythrogyne and D. aff. pallida "South Coast" tangled in the growth. I was impressed with the proportions of these species, which reached well over 2 meters in length as they climbed the surrounding vegetation, using their sticky leaves to latch onto the branches. At the other end of the scale, the diminutive Drosera modesta, with its wiry lime green stems and small shield shaped leaves blended in well with the surrounding moss. I was simply amazed at the diversity a single outcrop could hold and with a sense of encouragement, I set off to find more! 


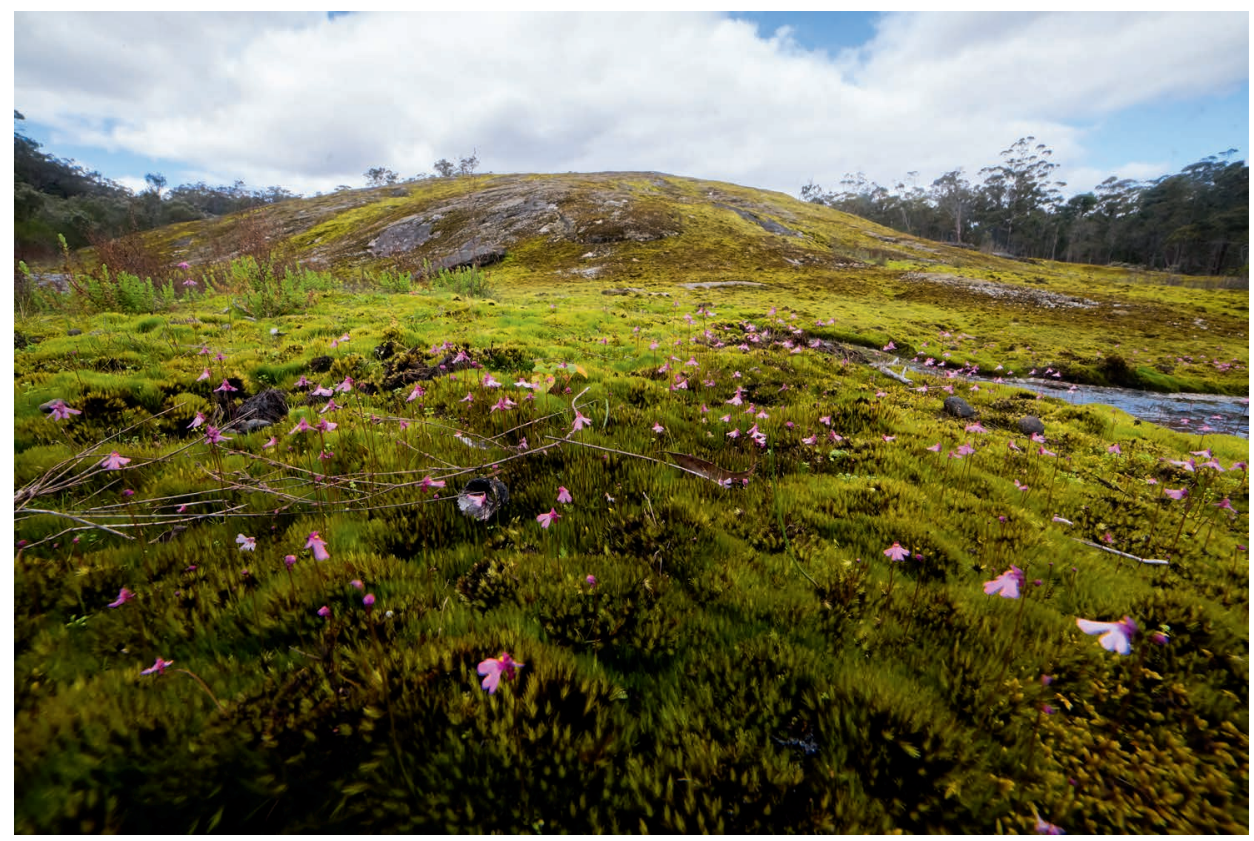

Figure 1: Utricularia multifida growing on a large granite outcrop in the forests of the South West region.

After visiting a few more similar sites, I started to understand the ecological role of the granite outcrops and why carnivorous plants congregated around them. In general, carnivorous plants require three conditions to grow: water, a nutrient poor substrate, and sunlight. In the forests of the South West, the first two abiotic factors are provided by the high rainfall which has leached the soils of their minerals. The limiting factor here is sunlight, as the forest canopy and thick undergrowth blocks light from reaching the ground. The open surface of the granite outcrops provides a break in the dense bushland, giving access to the light and space that is needed by plants. These plants are incredibly adapted for harsh conditions - in the summer, as the weather warms and rains decrease, the thin covering of moss in which the species grow completely dries up. The tuberous Drosera, which constitute the largest group of species in Western Australia, survive the annual desiccation by retreating back into a dormant corm, whilst annual species like Utricularia multifida race to grow to maturity within a single season and set seed before they die. These fragile habitats are reliant on the annual cycle of winter rains and cool weather to rehydrate them. They are therefore extremely sensitive to the systematic effects of climate change and not immune to destruction by humans, despite being physically protected within the boundaries of national parks.

As I approached the coast, the environment transitioned from dense forest to coastal heath. While the low-lying profile of the ecosystem meant that access to sunlight is no longer an issue, the dense undergrowth nonetheless limits the amount of space where carnivorous plants can colonize. Again, the granite outcrops, which ranged from large monoliths to flat surfaces, served an ecological role by providing a blank sunny slate amongst the surrounding vegetation. Each site seemed to host a unique combination of species and it was exciting to see what I would discover at every stop. At most locations, I observed Drosera erythrorhiza colonizing depressions where moss and peat could accumulate (Fig. 2). This highly variable species forms a large rosette of flat circular leaves and the 
plants in the region were mostly blushed with red. I also found a single population of D. huegelii, an erect species that grows a thin wiry stem adorned with dangling jellyfish-shaped leaves (Fig. 3). As the sun set, I finally arrived at Walpole exhausted and content with a very full day of discovery.

Over the next couple of days, I explored the coastal Great Southern region with interludes bashing around Cephalotus filled swamps and hiking in the endemic hotspot of the Stirling Range. Still, the occasional granite patch always provided reliable sightings of carnivorous plants. I was enamored one morning with Drosera purpurascens, a member of the Stolonifera complex that as its name suggests has stems of sprawling purple leaves (Fig. 4). The species in this section emerge towards the end of winter so, in contrast to the other tuberous species which were at the end of their growing season, D. purpurascens was at its physical prime. I found great beauty in the extremely dewy leaves sparkling like jewels amongst the shadows as they caught the low morning sun. Another interesting find was a granite-growing form of D. microphylla. This variety has large pink petals enclosed by red sepals and grew in mossy loam atop granite surfaces. This is in contrast to the heath growing form, which I observed to have small orange petals and golden sepals. Whilst the species has wide variation in color across its range (and color is not a valid taxonomic trait for distinguishing species), the combination of the separate niche occupation and color differences suggest at least some degree of genetic segregation. Perhaps in a few hundred thousand years they will diverge into something indisputably different and it was exciting to see evolution in process!

As my first week ended, I spotted Utricularia menziesii around the base of some large granite surfaces near Albany (Fig. 5). This species of terrestrial bladderwort is notable in both its appearance and adaptations to the Australian climate. Its large blood-red blooms have a long hanging protuberance that is somewhat reminiscent of the jacket tails of 18th century British soldiers, giving rise to its common name the "Redcoat". Their habitat, wet moss at the base of granite and swampy

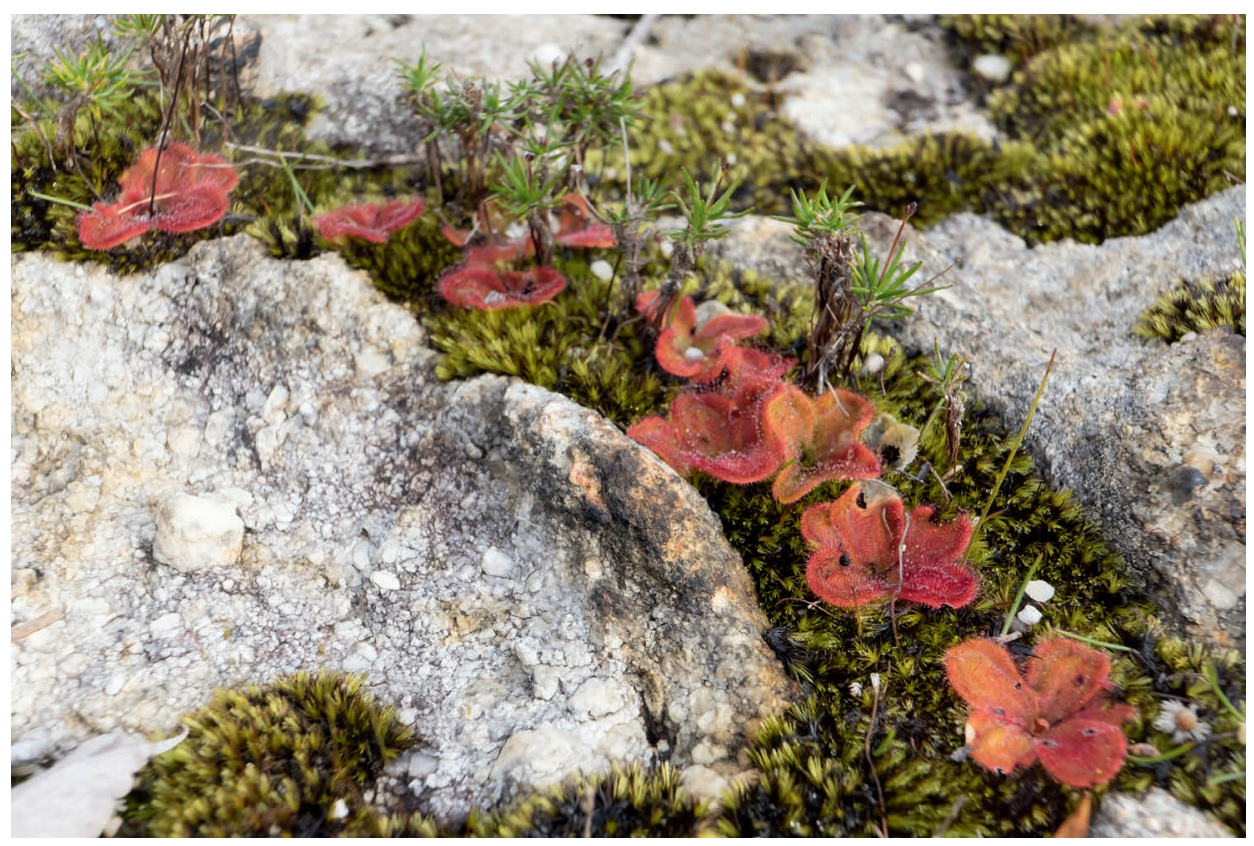

Figure 2: Drosera erythrorhiza. 


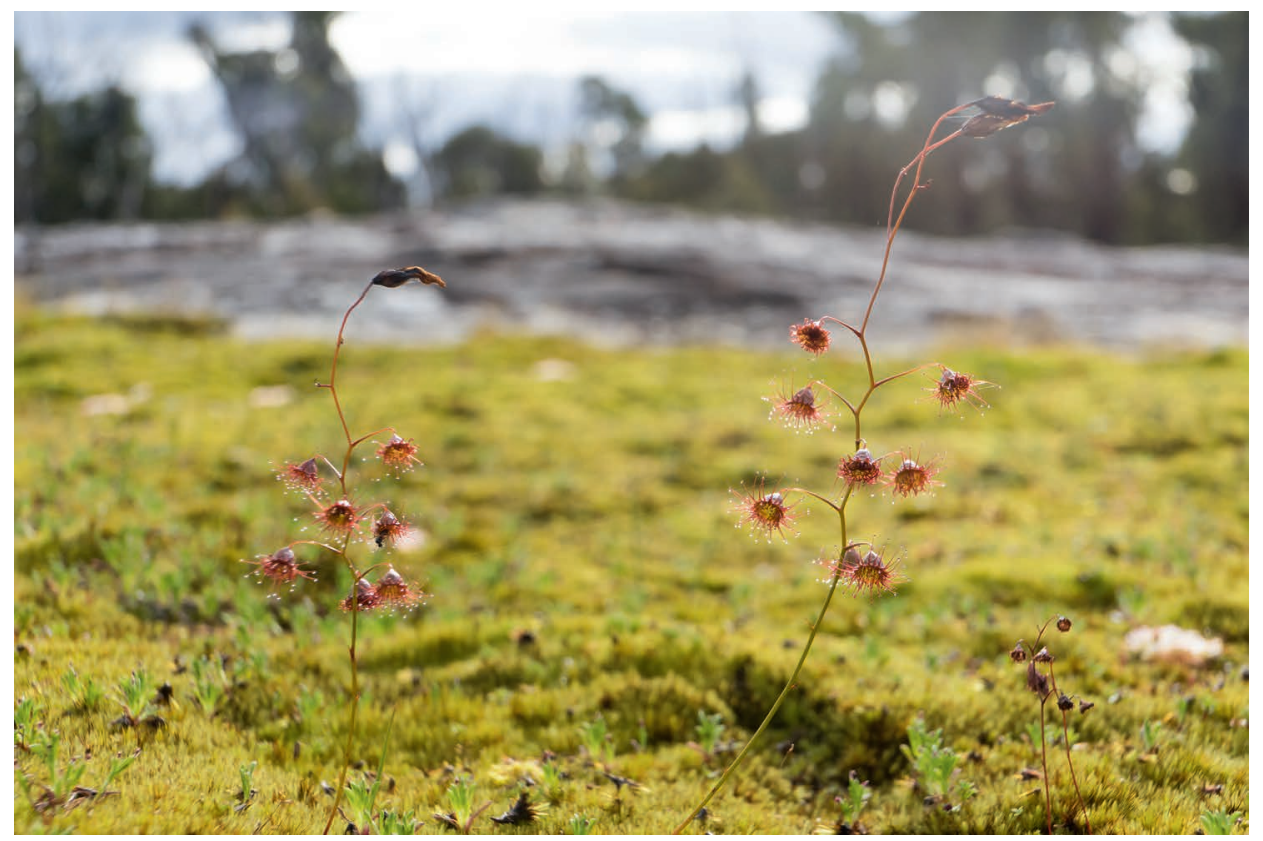

Figure 3: Drosera huegelii.

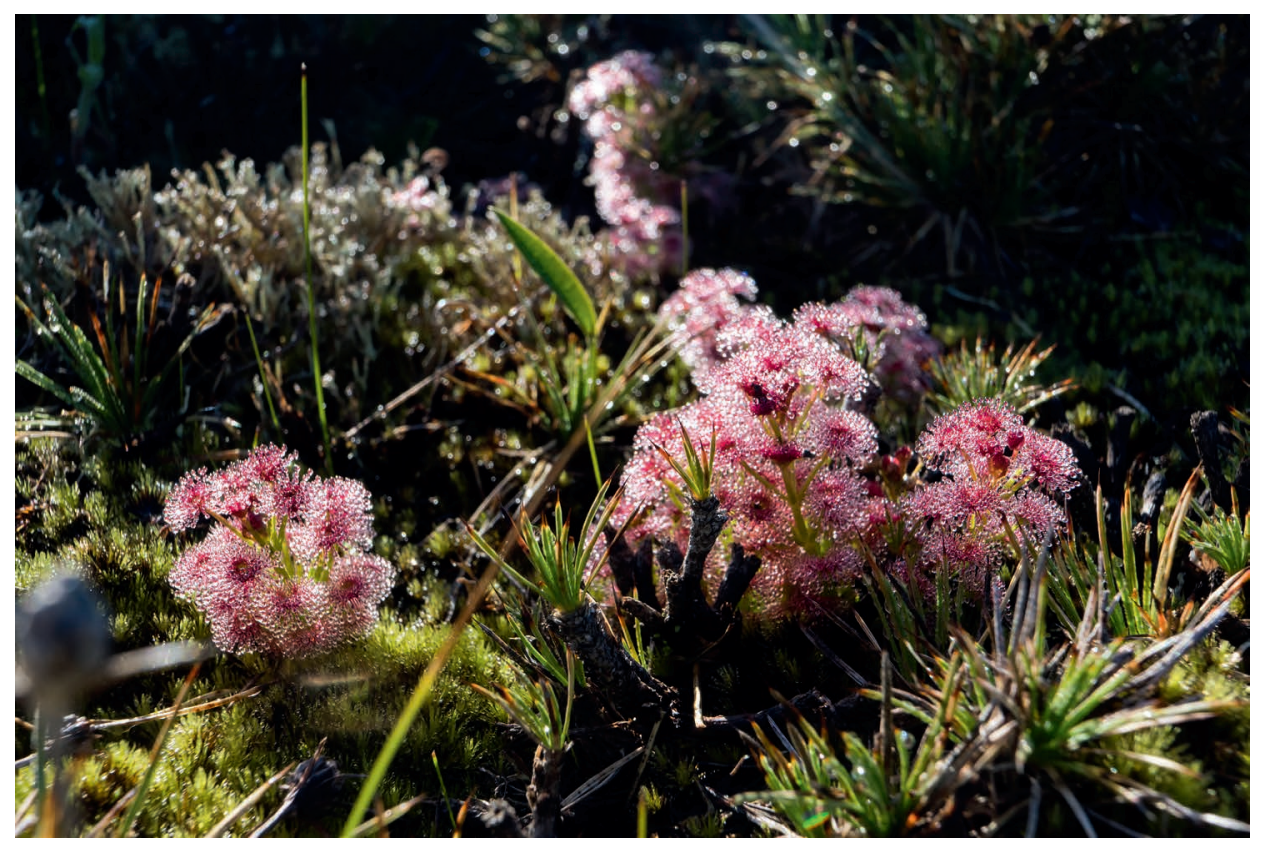

Figure 4: Drosera purpurascens. 


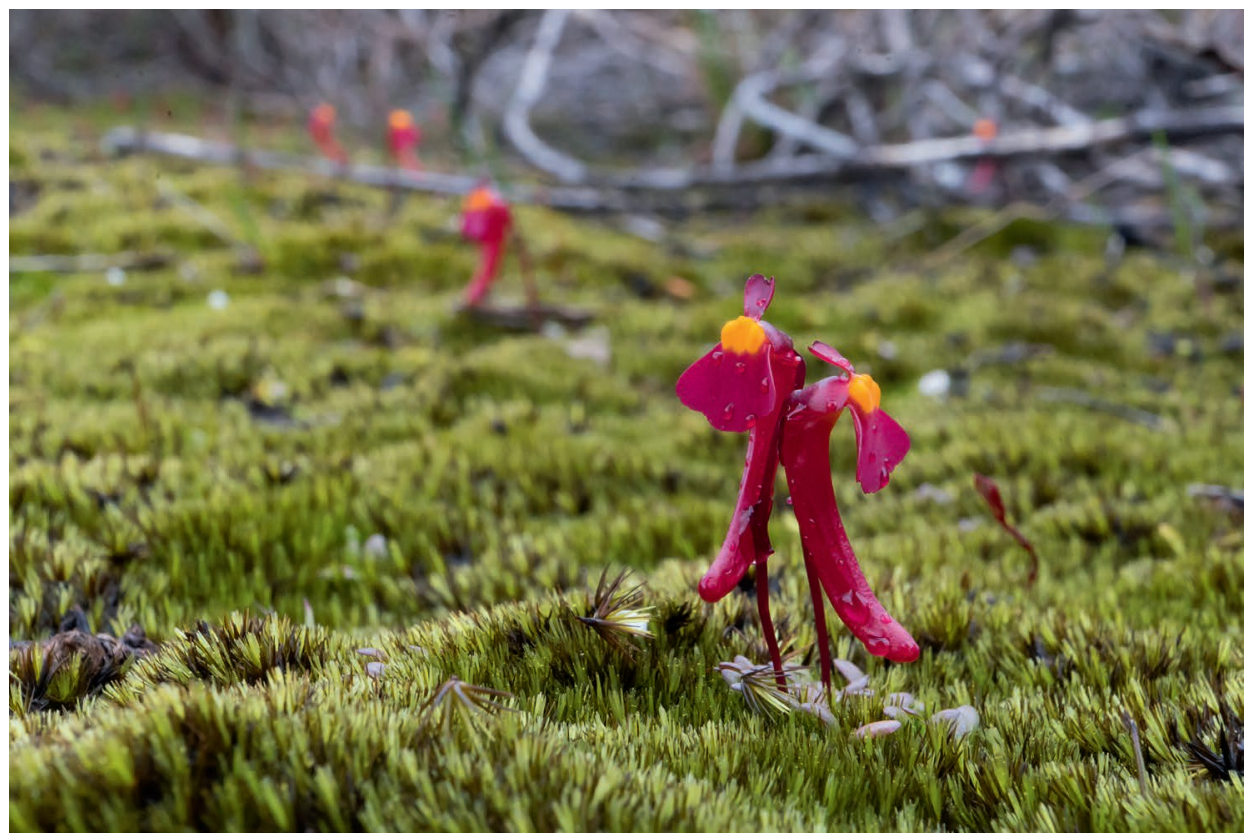

Figure 5: Utricularia menziesii.

water channels, dries up completely during summer. Unlike the annual Utricularia, this perennial species enters dormancy and forms a hibernating corm to survive the annual dehydration.

After a rewarding week of exploration in the Great Southern coast, my journey continued several hundred kilometers east towards the Fitzgerald River National Park before sweeping north to the agricultural Wheatbelt region near Hyden. The Wheatbelt is situated in the interior of Western Australia where winter rains and unending plains support the agriculture of wheat and canola. The land here has been extensively cleared for farming, replacing the indigenous semi-arid mallee shrubland and eucalypt woodland ecosystems. Paradoxically, this environmentally degraded region is also known for its intense biodiversity, which mainly congregates around the gigantic granite inselbergs that rise out of the surrounding plains as literal hills. These unfarmable monoliths and the small nature reserves that surround them provide crucial remnant patches of vegetation that protect an impressive diversity of flora and fauna, including many species of endemic Drosera. My plan for the next couple of days was to hop from outcrop to outcrop to see what I would discover.

It was soon to become evident that everything is bigger in the Wheatbelt. Coming to my first stop, I was immediately impressed by the grandeur of the outcrop and as it turns out, wholly unprepared for the sheer scale of the carnivorous plants that I was about to behold. As I approached the base of the rock, I noticed that the scrub was covered in strange patches of orange. Looking closer, I found Drosera macrantha and D. subhirtella growing to such densities that their matted stems formed a carpet that draped over the ground (Fig. 6). Giddy with excitement, I hurried forward to find vast colonies of D. bulbosa in the patches of moss on the rock surface and in the clay drainage field surrounding it (Fig. 7). The star shaped rosettes grew in abundance and littered the ground like confetti in shades ranging from bright yellow to dark purple. Confined to the moss was D. lowriei, a small species with a red mosaic of overlapping scale-like leaves. In the fields at the base of the outcrop, populations of $D$. glanduligera grew so densely that the ground gave off an orange sheen. 


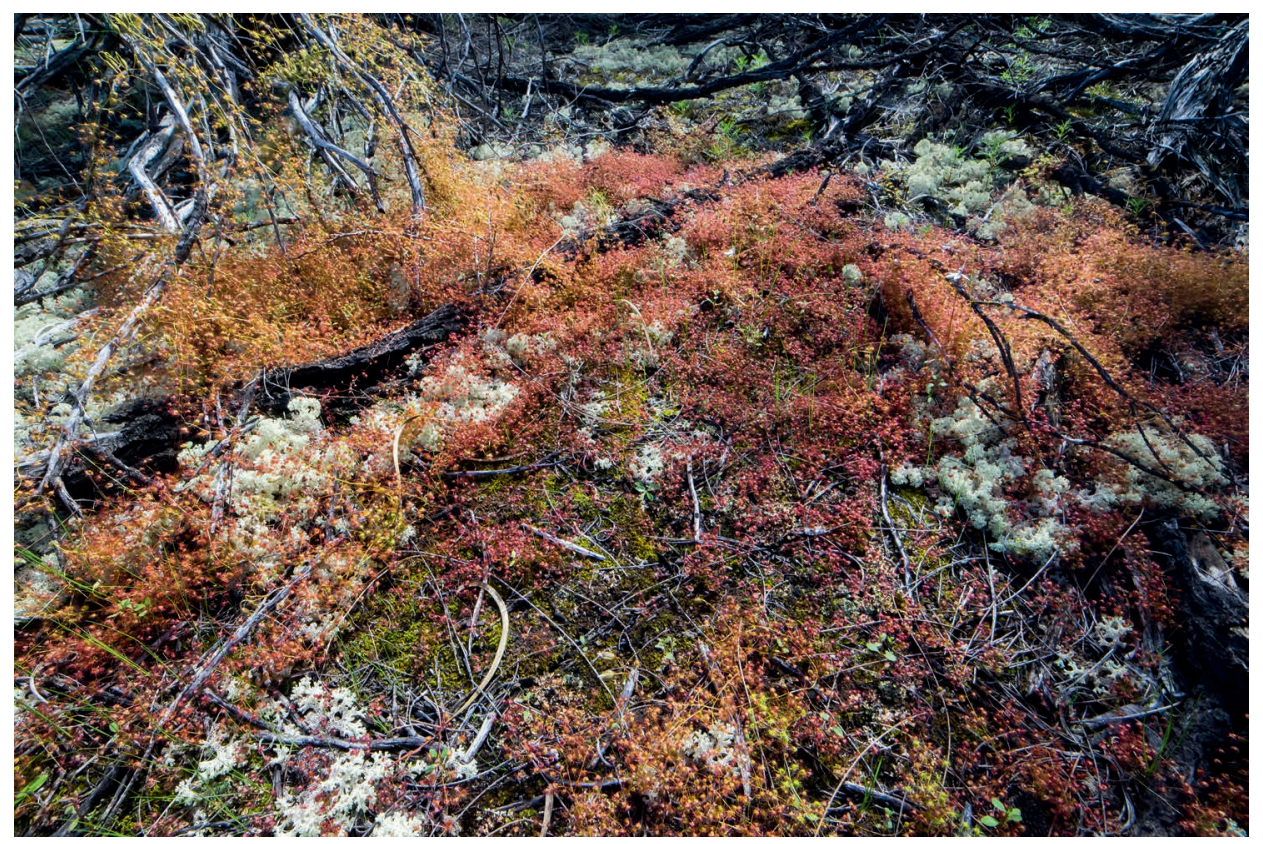

Figure 6: Masses of Drosera subhirtella and D. macrantha at the base of a granite outcrop in the Wheatbelt.

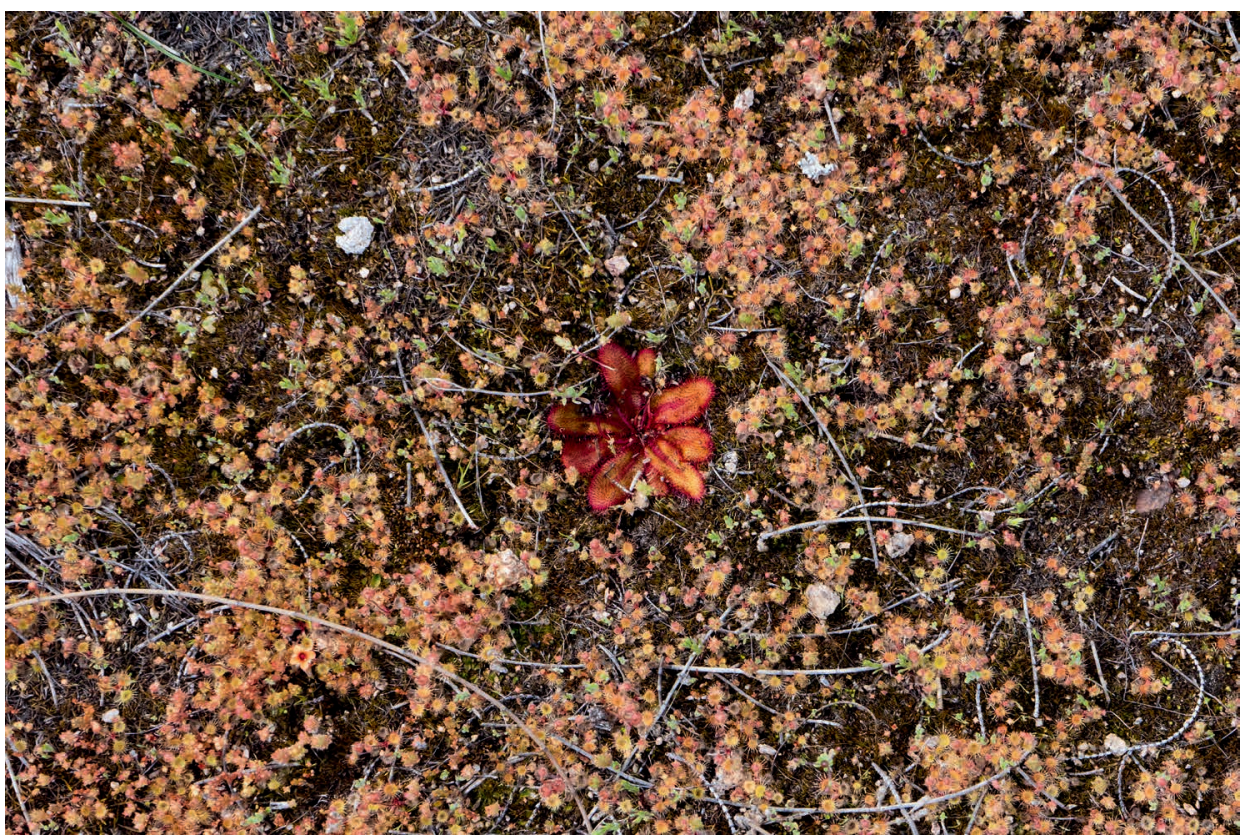

Figure 7: Drosera bulbosa surrounded by D. glanduligera. 
Never in my life had I seen so many sundews in such vast quantities and I was left awestruck at this life changing sight.

My sense of amazement was renewed at each outcrop and I began to appreciate the complex niches that these rocks gave rise to. As light and space is plentiful in the open plains of the Wheatbelt, it seemed that water was the limiting factor for plant growth. The sporadic winter rains are quickly soaked up by the sandy fields and most watercourses in the region are saline from the accumulation of minerals over millennia. The granite outcrops serve a critical ecological role by providing impermeable surfaces that channel and accumulate fresh water around their base. This property has been recognized for thousands of years by First Nations peoples to provide permanent sources of fresh water and has been appropriated since colonial times with the building of dam walls encircling these rocks, redirecting the water towards reservoirs. However, it was not until an evening rainstorm that I truly appreciated the capacity of the rocks to collect water. As the heavens opened up, the channels in the rock quickly swelled from trickles to gushing streams as flood waters submerged the Drosera lowriei (Fig. 8) and D. bulbosa that grew in the moss. At the base of the rock, depressions in the ground quickly filled up with pools of water, transforming the area into an ephemeral swamp. Thousands of D. rupicola grew in this waterlogged soil, their lime-green leaves and white flowers contrasting against the dark wet moss (Fig. 9). It was amazing to see how dramatically the rain transformed the outcrops into such a dynamic habitat.

The following morning, I decided to check out some tourist sites which mainly consisted of various popularized granite features. Visiting some well-known locations, I saw a similar variety of species as the day prior with the addition of the erect species Drosera yilgarnensis and D. stricticaulis. These two species occupied shallow moss beds at the edge of bushy patches on the rocks. Drosera yilgarnensis is distinguished by a well-developed basal rosette, red foliage and a brightly colored sepal structure, whereas the light green $D$. stricticaulis grows perfectly orbicular leaves. Whilst the

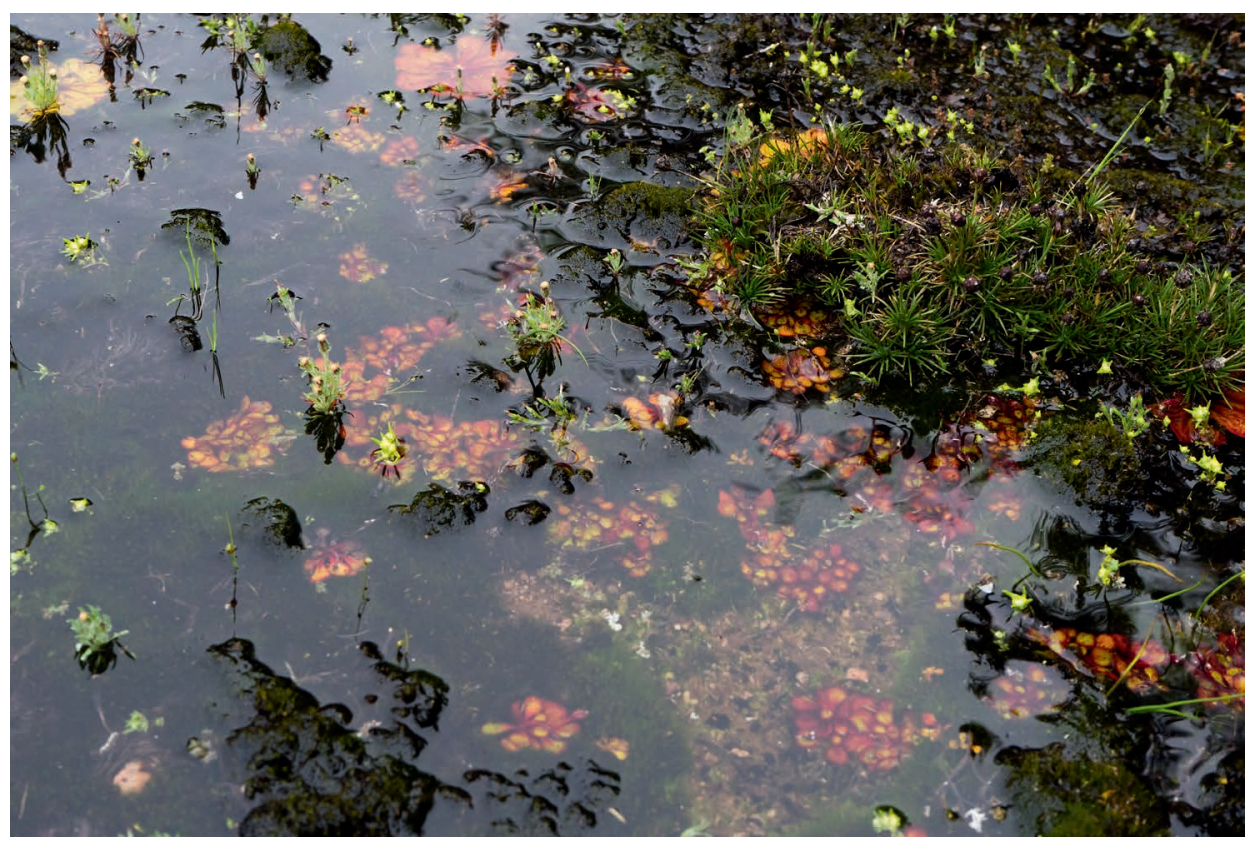

Figure 8: Drosera lowriei temporarily submerged during a downpour. 


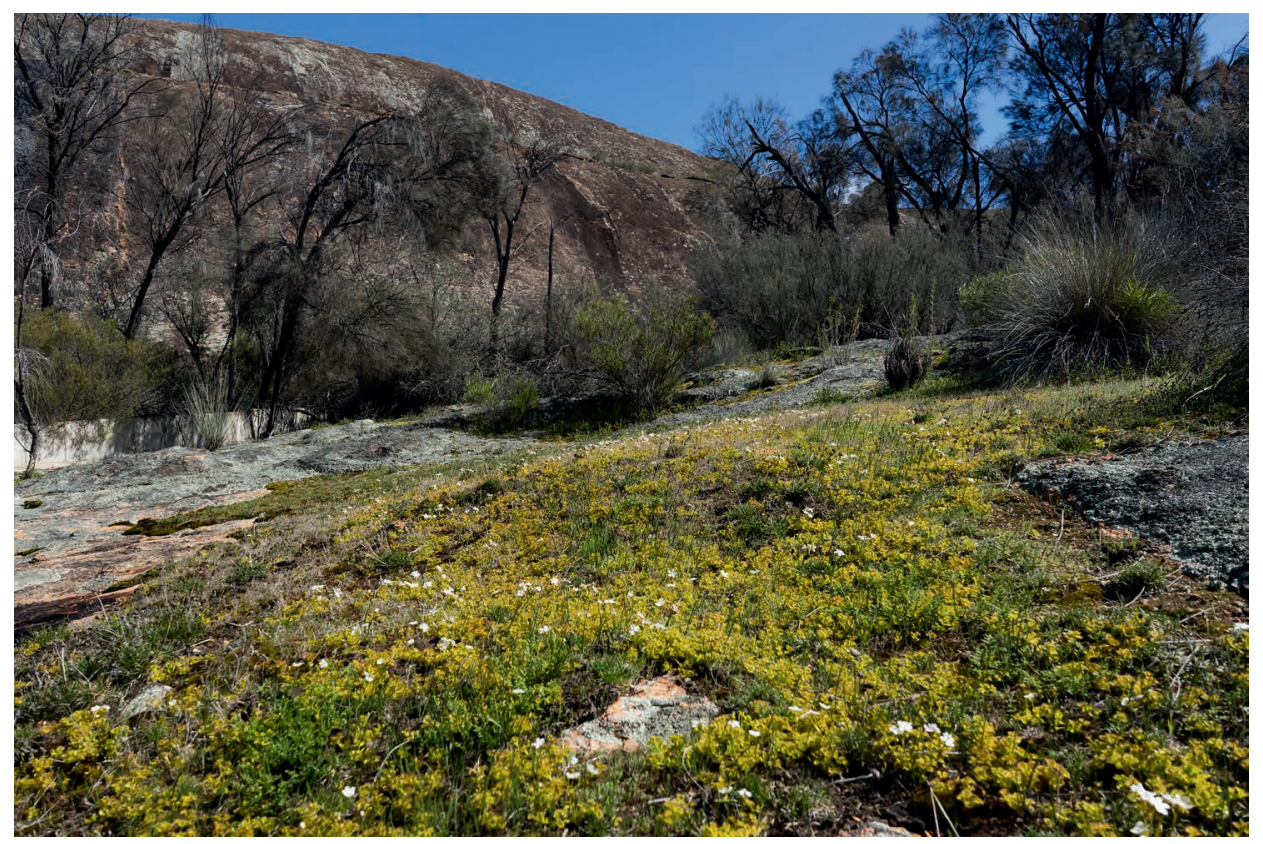

Figure 9: Drosera rupicola growing at a popular tourist site. A dam wall can be seen towards the left.

beauty of the tourist sites was indisputable, I couldn't help but notice some conspicuous signs of human degradation. Weeds grew in abundance in the drainage fields around the outcrops, no doubt introduced by the shoes of the hundreds of daily visitors. On the rock surfaces, it was evident that the fragile moss gardens were trampled over, especially when they occurred near walking paths. Perhaps the most distressing example was the motorcycle tracks that brazenly scarred the delicate moss fields that covered the flatter outcrops.

I resolved to find a more undisturbed site to compare with and using Google Maps, I located a particularly remote granite outcrop protected well within the boundary of a large reserve. After a while of navigating through old paths and animal tracks, I was rewarded with one of the most beautiful sights I have ever seen. Around the entire base of the rock were dense fields of the eponymous Drosera graniticola (Fig. 10) growing in the thousands, their rust colored stems tinging the landscape with a metallic sheen as they swayed in the breeze. Against the low afternoon sun, the fields seemed to glow as the plants caught the light in their dew. This species grows impressive bouquets of flowers, with en mass displays that surely rival the non-carnivorous wildflowers that the Western Australian countryside is known for. While I had seen isolated patches of $D$. graniticola at previous locations, this undisturbed site was by far the most impressive stronghold for this "Priority Four" rare species, providing protection and allowing it to proliferate to impressive numbers. For me, it was one of the most apparent examples of successful conservation and truly reinforced the need to protect these wonderful locations from human destruction, both intentional and otherwise.

By now, I had been on the road for an exhausting 10 days. Eager to make the most of my final week, I continued back towards the west coast, allocating some time exploring the laterite hills of the north, before returning down south to Perth. My last few days were spent in the Darling Range, a hilly escarpment of granite that runs parallel to the coast and separates it from the Wheatbelt. This 


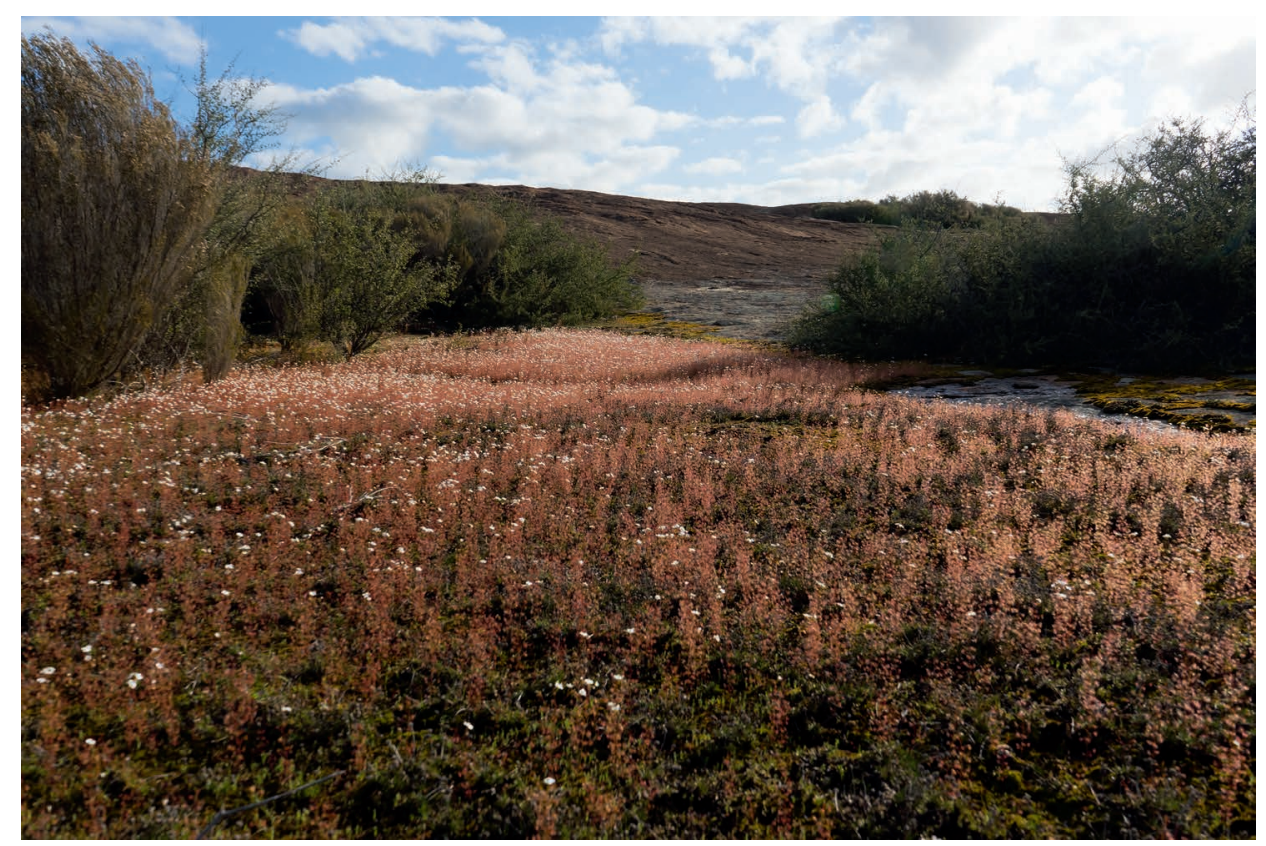

Figure 10: Drosera graniticola growing en mass around a remote granite outcrop.

elevated geographical feature forces the humid coastal air to rise and precipitate rain, a process known as orthographic lift, that contributes to locally high rainfall in the region. Like the South West, the wetness supports extensive forests of gigantic trees and the granite outcrops once again provided a break amongst the growth. Driving back to Perth, I found a beautiful site in an area earmarked for urbanization in the ridges of the Avon Valley. On a flat rock face that was covered with wet moss, I saw a field sparking from hundreds of Drosera heterophylla (Fig. 11). This water loving species is unique within the genus for producing flowers with many more petals than the usual five and is known for its especially lustrous dew.

As my time in Western Australia drew to an end, I decided to cap off my trip with a long mountainous hike deep in the Perth Hills. Despite all the amazing sites I had seen every day for more than 2 weeks, I was once again awed by the Drosera that grew in great abundance on the granite outcrops. I found Drosera bulbosa and D. rosulata, which in this area sometimes look very similar to each other in that they both can have rounded deep-red leaves. The latter species can be distinguished by a sunken central vein and slight preference of loam over moss. Once again, D. pallida and D. macrantha occupied the shrubs on and around the rocks in impressive numbers (Fig. 12). The scrambling stems reminded me of flames as they emerged from the bushes in lustrous shades of copper and gold, their dew illuminated against the sunlight. A new discovery was made in the sighting of $D$. menziesii. This vibrant red erect species grew in the thousands in the mossy drainage fields of low-profile rock surfaces in the area.

But the species I wanted to see the most was the iconic Drosera gigantea, which has always captured my imagination with its branching tree-like morphology. This species is probably the last of the tuberous sundews to emerge, breaking dormancy at the end of winter and growing well into the summer. Its early growth phase, which has an uncanny resemblance to asparagus stems, could be seen everywhere poking out of the wettest soils but I was yet to find mature specimens in any 


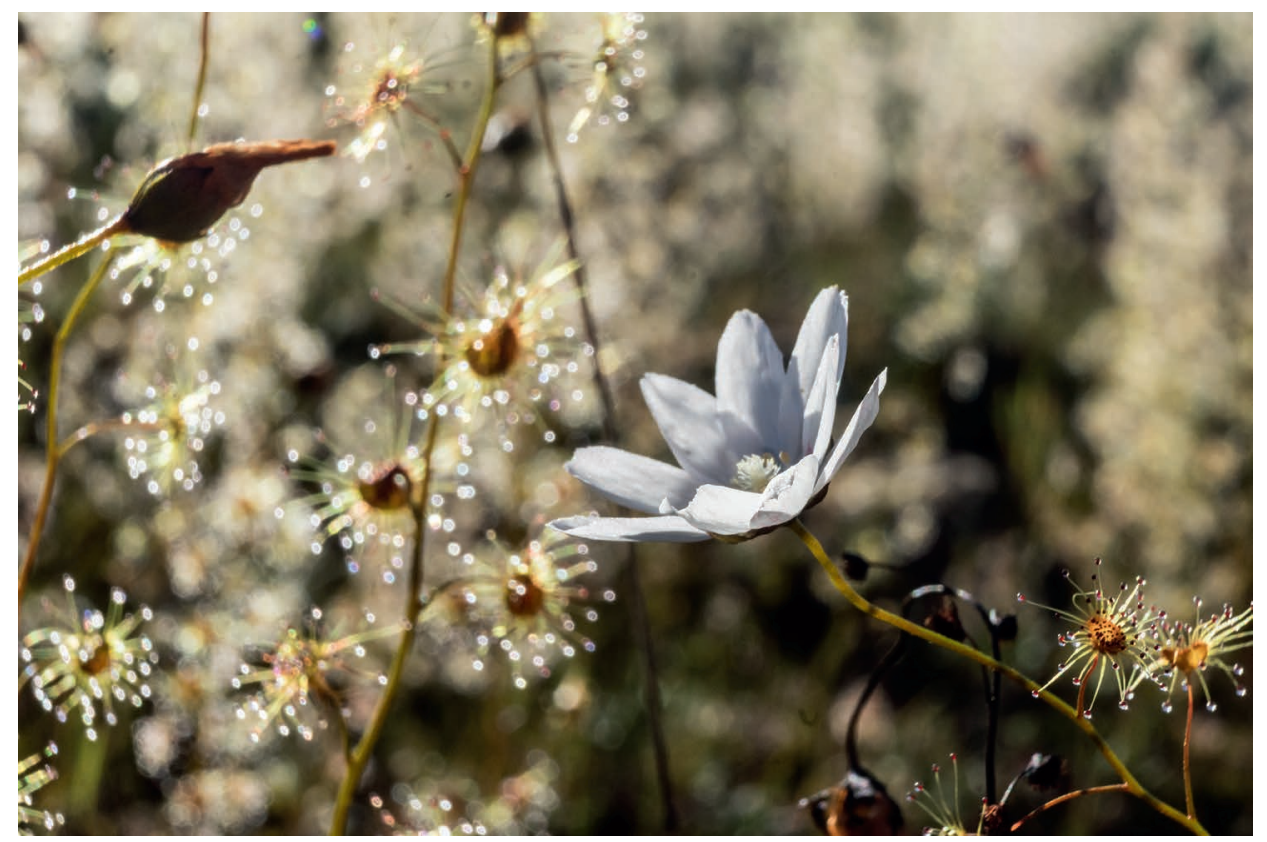

Figure 11: Drosera heterophylla.

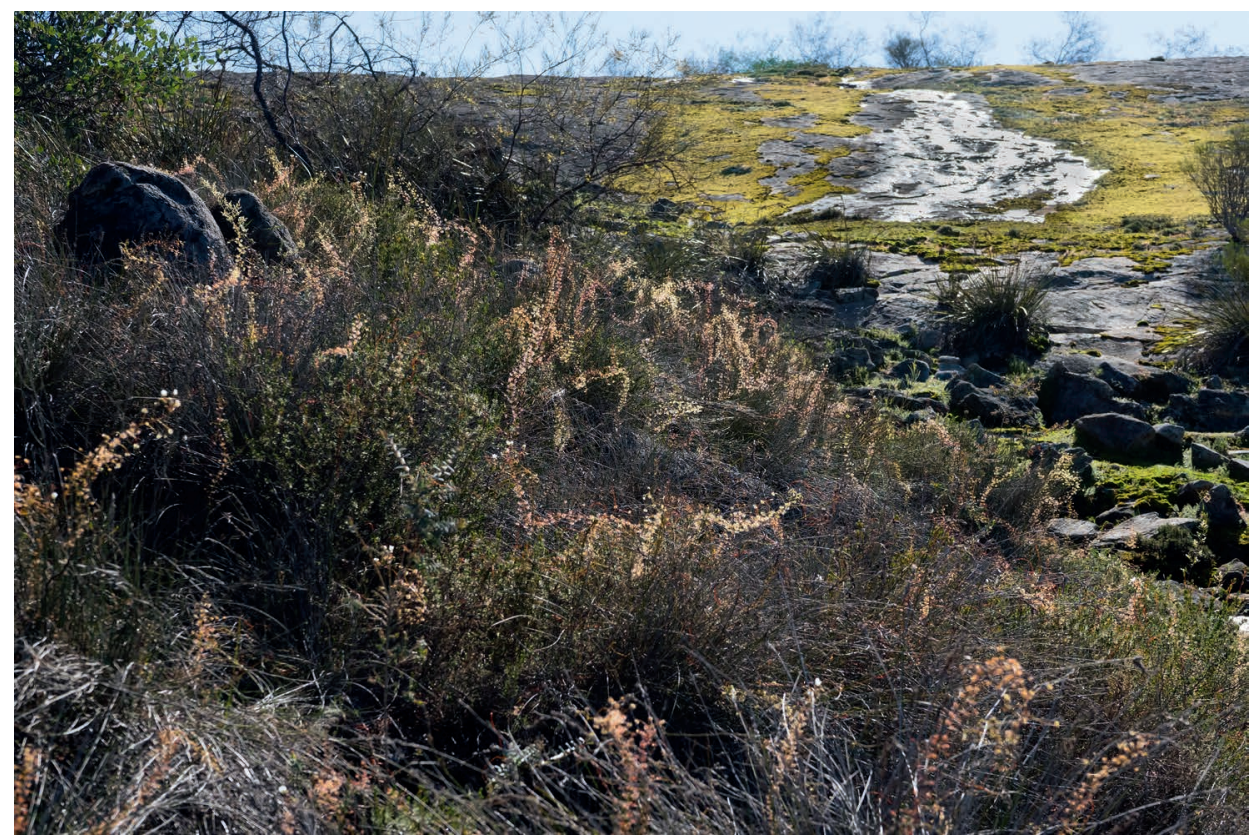

Figure 12: Drosera pallida and D. macrantha in the Perth Hills. 


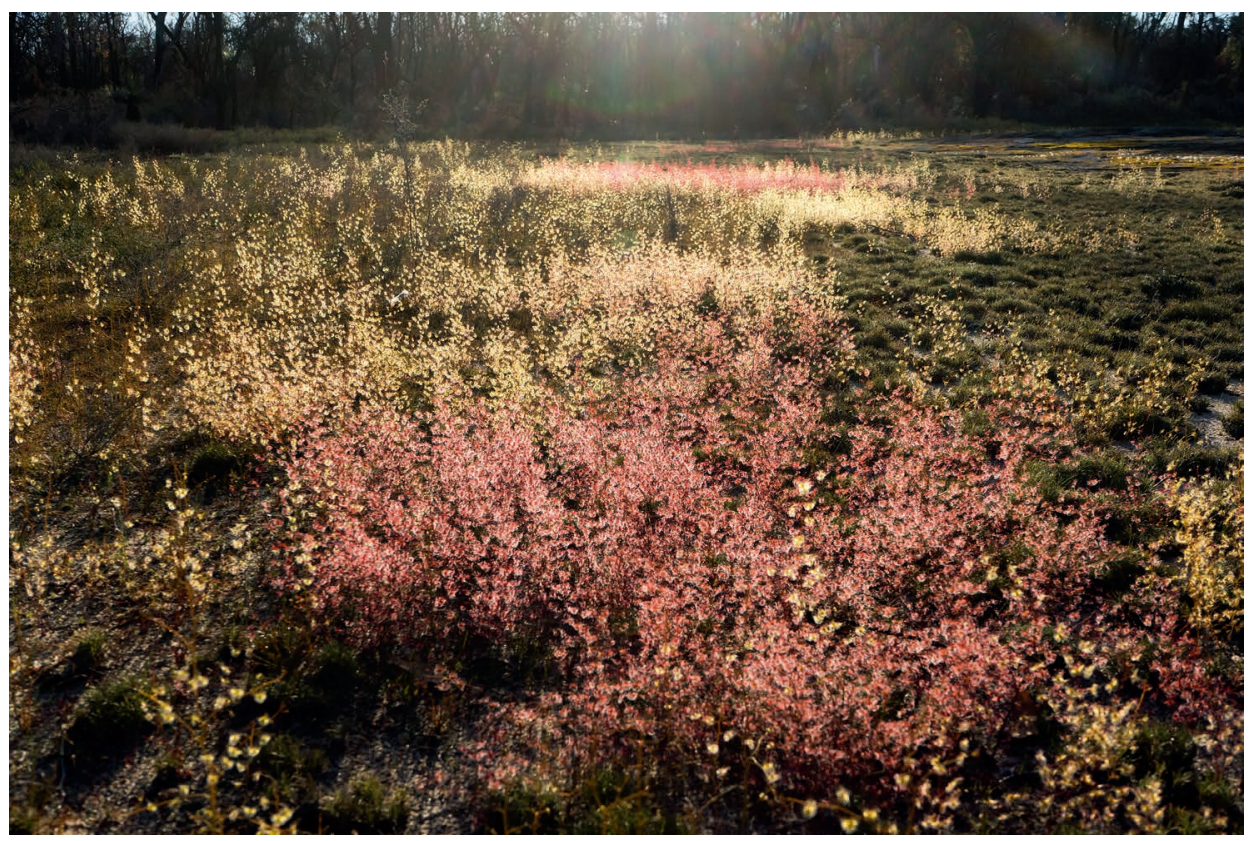

Figure 13: A field of the red and green forms of Drosera gigantea.

impressive quantity. My prayers were finally answered as I reached the last site of my last day. Amongst a recently burned patch of forest, I spotted the familiar glow of sundews in the swampy field of a small outcrop. Both the green and red form of $D$. gigantea grew alongside each other in great numbers, all plants displaying a full set of foliage (Fig. 13). It appeared that the recent fires and sub-flowering age of the plants had stimulated them to grow leaves relatively early at this particular site. Against the golden light of the late afternoon sun, the area came alive with patches of sparkling leaves, their vibrant aura contrasting dramatically against the shadows. For the first time in my hectic journey, I just paused and took in the beauty around me and as the sun set over the field of Drosera I knew that I was fully satisfied with my expedition.

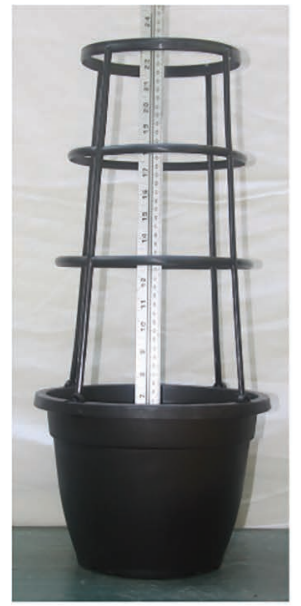

\section{Ferocious Foliage.com}

Custom Tissue Culture Laboratory

\section{Terrific alternative to a hanging basket.}

Pots are $10^{\prime \prime}$ in diameter, $71 / 4^{\prime \prime}$ tall with a 1.75 gallon capacity.

Terraces are $141 / 2$ " tall.

info@ferociousfoliage.com

$$
\begin{aligned}
& \$ 5.00 \text { each }+\mathrm{S} / \mathrm{H} \\
& \text { Ferocious Foliage } \\
& \text { P.O. Box } 458
\end{aligned}
$$

Dahlonega, GA 30533

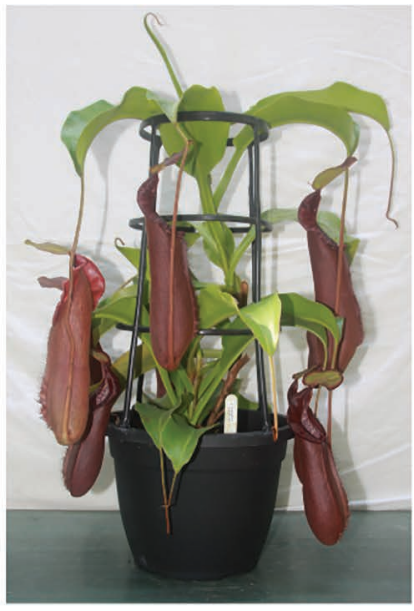

Plant not included 